\section{Minimum Climatic Temperature}

A RECENT note by C. F. Talman of the United States Weather Bureau, one of the "Why the Weather?" series issued by Science Service, Washington, D.C., describes an observation of some interest for those who attach importance to climatic extremes. The note states that when Archdeacon Stuck climbed Mount McKinley, Alaska, in 1913, he placed a minimum thermometer in a small wooden case and fastened it securely in a cleft of rock at a height of 15,000 feet above sea level. When the thermometer was recovered last May, it was found that the index was down in the bulb, and indicated a minimum at least as low as $-100^{\circ} \mathrm{F}$. Mr. Talman finds it difficult to say how much confidence can be placed in the observation; one possibility suggested is that vibration due to strong wind caused the index to fall below what should have been its lowest position. According to the 1930 edition of the "Meteorological Glossary" of the Meteorological Office, Air Ministry, the lowest temperature recorded at the earth's surface is $-93 \cdot 6^{\circ} \mathrm{F}$. at Verkhoïansk, Siberia, on January 3 , 1885. There is now at least one colder place in Siberia than Verkhoïansk equipped as a climatological station; such a place would probably have yielded a lower reading than $-93 \cdot 6^{\circ}$ had it been in operation in 1885 . In the free air, much lower readings have been recorded at greater heights in low latitudes, where the normal fall of temperature with height is maintained to such high levels that in spite of the relative warmth near the ground a lower temperature is recorded than at any height in temperate or high latitudes. The "Meteorological Glossary", for example, refers to a reading of $-131 \cdot 6^{\circ} \mathrm{F}$. obtained at a height of about 54,000 feet above Batavia, Java.

\section{Archæology and Tradition}

THE Sir John Rhys memorial lectures of the British Academy, inaugurated in $\mathbf{1 9 2 5}$ and delivered annually since that date, have now secured, as a series, a place in Celtic studies worthy of the great scholar they commemorate. The lectures have been apposite in subject and the lecturers have never failed to stimulate interest in their special field. The latest lecture to be published (London: Oxford University Press. 1s. 6d. net), by Prof. H. Fleure on "Archæology and Folk-Tradition", deals with a matter of interest to both archæologist and folklorist, but perhaps at the present stage in archæological studies, more particularly to the former. The illustration, or perhaps illumination, of conclusions derived from archæological data by reference to tradition and legend may become an alluring, but somewhat hazardous, exercise in ingenuity. Prof. Fleure's suggested relation of "The Twilight of the Gods" to a period of climatic deterioration and racial unrest in bronze age Europe is suggestive, but at the same time by its very restraint inculcates caution in those who have not his wide knowledge of the archæological aspects of ancillary sciences such as meteorology, botany, and geography, which is essential for a synthesis such as he essays. Turning more specifically to Britain and the relation of British and Irish archæology to Celtic tradition, his interpretation, for example, of Irish ethnic tradition shows by precept and example how at each stage the argument must adhere rigidly to ascertained fact. Yet notwithstanding his caution, Prof. Fleure feels able to place some reliance on the traditional Spanish connexion of early Irish peoples and incidentally to offer an enlightening suggestion as to the possible origin of the obscure Tuatha de Danann.

\section{Submarine Telephone Cables at Carrier Frequencies}

IN ordinary telephony the sound waves falling on the microphone vary the pressure on the carbon granules through which a current is flowing. The resistance of the circuit thus varies, and so the current varies with the sound wave and in the receiver produces sound waves exactly similar to the original waves. In radio-telephony, in place of the current in the connecting wires, we have a highfrequency current emitted from the transmitter. This is varied (modulated) by the sound waves. These modulated waves falling on a suitable receiver reproduce waves similar to the original sound waves. Better results are obtained by using conducting wires, and in particular submarine cables. The cost of the cable in this case makes it necessary that it should carry pairs of wires providing several channels of communication. The disadvantage of this type of cable is the great difficulty of laying and maintaining it in deep water. For deep sea work a single core cable is used provided with a copper sheath under the armouring to carry the return current. In 1920 the serious single-channel limitation of this type of cable was overcome by the use of carrier wave high frequencies. This enabled telephone cables to be laid and operated between Key West (Florida) and Havana, a distance of 103 nautical miles. In a paper read to the Institution of Electrical Engineers on February 23, Dr. E. W. Smith discusses the electrical requirements for this type of transmission. He also summarises the most recent advances in materials and methods of con. struction and indicates probable future developments.

\section{A Modern Granary}

What is described as the largest granary in South America, and in equipment, probably the most complete in the world, is described in Engineering for February 10 and 24 and March 10. The granary has recently been erected by the Buenos Aires Great Southern Railway at the port of Bahia Blanca, Argentina, at a cost of about $£ 1,000,000$. The plant consists of an unloading station for the discharge of grain from the railway wagons, a ferroconcrete granary of 80,000 tons capacity, a loading jetty and shipping galleries. For the transport of the grain there are no fewer than 120 conveyors having more than twelve miles of conveyor and elevator belting. The whole plant is driven electrically, current being supplied from a sub-station to some 240 electric motors of an aggregate horse power of about 10,000. Some idea of the capacity of the plant can be obtained. from the statement that, while grain can be unloaded continuously at the rate of 1,000 tons an hour, on the outgoing side six ocean-going ships can each be 